\title{
KAJIAN SYAIR KREASI AGUNG PURNOMO
}

\section{Muhimmatun Nimah}

Universitas Nahdlatul Ulama Sidoarjo

\section{PENGANTAR}

Puisi adalah nama kolektif untuk semua jenis puisi. Seorang penulis puisi (penyair atau penyair) melakukan yang terbaik untuk membuat teksnya seindah mungkin. Dalam teks puitis, seorang penyair mencoba mengatakan sebanyak mungkin dengan sesedikit mungkin kata. Jadi setiap kata dalam puisi dipikirkan dengan baik. Puisi telah ditulis sejak lama. Penyair menulis karena berbagai alasan: untuk menghibur orang, untuk mengajari mereka sesuatu, untuk mengatakan sesuatu tentang perasaan mereka, untuk memperjelas bagaimana mereka memandang dunia, untuk menyampaikan pesan politik atau karena mereka ingin bermain dengan bahasa (Wikikids, 2018). 
Puisi merupakan bentuk sastra yang digunakan penyair ketika mereka mengekspresikan suasana hati dan perasaan secara umum dengan beberapa kata. Panjang garis tergantung pada pilihan penulis. Puisi adalah bentuk sastra, dengan sejumlah karakteristik eksternal: garis pendek (non-kontinu), cermin halaman besar, meter, sajak, kepadatan informasi (Kernerman Dictionaries, 2019).

Mengapa semua orang harus membaca puisi?. Semakin banyak penelitian yang menunjukkan betapa pentingnya membaca untuk anak-anak (muda). Ini tidak hanya penting untuk pengembangan bahasa anak Anda dan keterampilan membaca, tetapi juga meningkatkan empati, merangsang imajinasi, menciptakan ikatan yang aman antara Anda dan anak Anda, dan mendorong semua jenis keterampilan kognitif. Membaca orang tua mungkin pertama-tama menggunakan buku bergambar atau kumpulan buku, dan buku-buku itu tentu sangat bagus. Membaca puisi sangat menyenangkan dan menawarkan banyak manfaat 
tambahan. Anak-anak yang mengerti sajak dengan baik akan belajar membaca dengan lebih mudah. Dengan mendengarkan sajak, anak-anak belajar membedakan bunyi mana dalam satu kata yang sama dan mana yang berbeda. Itu membuatnya lebih mudah nanti untuk juga membedakan huruf di atas kertas. Penelitian terbaru menunjukkan bahwa anakanak dengan disleksia terutama berjuang dengan kata ritme. Puisi meningkatkan kosakata dan memori. Puisi merangsang fantasi dan kreativitas (Pelseneer, 2015). 


\section{TABEL 1. SYAIR KARANGAN AGUNG PURNOMO}

\begin{tabular}{|c|c|c|c|c|c|c|}
\hline No & $\begin{array}{l}\text { Judul } \\
\text { buku }\end{array}$ & $\begin{array}{l}\text { Judul } \\
\text { Puisi } \\
\end{array}$ & Penulis & $\begin{array}{l}\text { Jenis } \\
\text { puisi }\end{array}$ & Tahun & Penerbit \\
\hline 1 & $\begin{array}{l}\text { Kidung } \\
\text { Nawala } \\
\text { (Jilid 1) }\end{array}$ & \#CH1 & $\begin{array}{l}\text { Agung } \\
\text { Purnomo }\end{array}$ & Puisi Bebas & 2018 & $\begin{array}{l}\text { UNUSIDA } \\
\text { Press }\end{array}$ \\
\hline 2 & $\begin{array}{l}\text { Tenta } \\
\text { Kimaya }\end{array}$ & Menyala & $\begin{array}{l}\text { Agung } \\
\text { Purnomo }\end{array}$ & Puisi Haiku & 2019 & $\begin{array}{l}\text { STIEBA } \\
\text { Madura } \\
\text { Press } \\
\end{array}$ \\
\hline 3 & $\begin{array}{l}\text { Syair } \\
\text { Nimala } \\
\end{array}$ & Berpulang & $\begin{array}{l}\text { Agung } \\
\text { Purnomo }\end{array}$ & Puisi epitaf & 2019 & $\begin{array}{l}\text { STIEBA } \\
\text { Madura } \\
\text { Press } \\
\end{array}$ \\
\hline 4 & $\begin{array}{l}\text { Bhumi } \\
\text { Bawera }\end{array}$ & Tangisnya & $\begin{array}{l}\text { Agung } \\
\text { Purnomo, } \\
\text { Nur Asitah }\end{array}$ & $\begin{array}{l}\text { Puisi } \\
\text { Naratif }\end{array}$ & 2019 & $\begin{array}{l}\text { STIEBA } \\
\text { Madura } \\
\text { Press } \\
\end{array}$ \\
\hline 5 & $\begin{array}{l}\text { Tolesan } \\
\text { Aditi }\end{array}$ & Pandai & $\begin{array}{l}\text { Agung } \\
\text { Purnomo, } \\
\text { Nur Asitah }\end{array}$ & $\begin{array}{l}\text { Puisi } \\
\text { Riddle }\end{array}$ & 2019 & $\begin{array}{l}\text { STIEBA } \\
\text { Madura } \\
\text { Press }\end{array}$ \\
\hline 6 & $\begin{array}{l}\text { Arebhan } \\
\text { Helai }\end{array}$ & $\begin{array}{l}\text { Sepekan } \\
\text { Awal } \\
\text { Tanpamu }\end{array}$ & $\begin{array}{l}\text { Agung } \\
\text { Purnomo, } \\
\text { Nur Asitah }\end{array}$ & $\begin{array}{l}\text { Puisi } \\
\text { bersekuen }\end{array}$ & 2019 & $\begin{array}{l}\text { STIEBA } \\
\text { Madura } \\
\text { Press } \\
\end{array}$ \\
\hline 7 & $\begin{array}{l}\text { Lembhar } \\
\text { Jiwana }\end{array}$ & Cantik & $\begin{array}{l}\text { Agung } \\
\text { Purnomo, } \\
\text { Nur Asitah }\end{array}$ & $\begin{array}{l}\text { Puisi } \\
\text { Jenaka } \\
\text { Limerick }\end{array}$ & 2019 & $\begin{array}{l}\text { STIEBA } \\
\text { Madura } \\
\text { Press }\end{array}$ \\
\hline 8 & $\begin{array}{l}\text { Rassana } \\
\text { Jlantir }\end{array}$ & $\begin{array}{l}\text { Rindu di } \\
\text { Ubun- } \\
\text { Ubun }\end{array}$ & $\begin{array}{l}\text { Agung } \\
\text { Purnomo }\end{array}$ & Puisi Bebas & 2019 & $\begin{array}{l}\text { STIEBA } \\
\text { Madura } \\
\text { Press }\end{array}$ \\
\hline 9 & $\begin{array}{l}\text { Suweda } \\
\text { Ate }\end{array}$ & Kita & $\begin{array}{l}\text { Agung } \\
\text { Purnomo, } \\
\text { Elsa } \\
\text { Rosyidah }\end{array}$ & Puisi Bebas & 2019 & $\begin{array}{l}\text { STIEBA } \\
\text { Madura } \\
\text { Press }\end{array}$ \\
\hline 10 & $\begin{array}{l}\text { Dhalubang } \\
\text { Marta }\end{array}$ & $\begin{array}{l}\text { Bapak } \\
\text { Samsuri } \\
\end{array}$ & $\begin{array}{l}\text { Agung } \\
\text { Purnomo, } \\
\text { Nur Asitah }\end{array}$ & $\begin{array}{l}\text { Puisi } \\
\text { Clerihew }\end{array}$ & 2019 & $\begin{array}{l}\text { STIEBA } \\
\text { Madura } \\
\text { Press }\end{array}$ \\
\hline 11 & $\begin{array}{l}\text { Kidung } \\
\text { Nawala } \\
\text { (Jilid 2) }\end{array}$ & Dua Kaki & $\begin{array}{l}\text { Agung } \\
\text { Purnomo }\end{array}$ & Puisi Bebas & 2018 & $\begin{array}{l}\text { UNUSIDA } \\
\text { Press }\end{array}$ \\
\hline
\end{tabular}




\section{PENYAIR}

Penyair yang diulas dalam tulisan ini bernama Agung Purnomo dan tumbuh di Sidoarjo, Jawa Timur. Beliau merupakan salah satu seorang penulis produktif. Berikut tulisan syair beliau telah disebarkan secara luas melalui penerbit nasional, yaitu: STIEBA Madura Press, dan UNUSIDA Press.

\section{KAJIAN SYAIR}

Beberapa syair kreasi sang penulis Agung Purnomo yakni: \#CH1 (Purnomo, 2018a), cantik (Purnomo \& Asitah, 2019b), rindu di ubun-ubun (Purnomo, 2019c), sepekan awal tanpamu (Purnomo \& Asitah, 2019d), berpulang (Purnomo, 2019a), dua kaki (Purnomo, 2018b), bapak Samsuri (Purnomo \& Asitah, 2019a), menyala (Purnomo, 2019b), tangisnya (Purnomo \& Asitah, 2019e), kita (Purnomo \& Rosyidah, 2019) dan pandai (Purnomo \& Asitah, 2019c).

Sungguh menarik dan menggoda membaca beberapa syair kreasi penulis. Agung Purnomo telah 
mengarang sekitar sebelas puisi dengan gaya epitaf, clerihew, bebas, riddle, bersekuen, jenaka limerik dan haiku. Puisi diterbikan pada tahun 2018 dan tahun 2019. Sangat direkomendasikan membaca tulisan Agung. Penulis menggandeng penulis lain yaitu Nur Asitah dan Elsa Rosyidah untuk berkarya.

\section{REFERENCES}

Kernerman Dictionaries. (2019). Poezie. Retrieved June 24, 2019, from http://www.woorden.org/woord/poëzie Pelseneer, R. De. (2015). Waarom iedereen zijn kinderen poëzie zou moeten voorlezen. Retrieved June 23, 2019, from https://volvanzinnen.be/2015/09/waaromiedereen-zijn-kinderen-poezie-zou-moetenvoorlezen/

Purnomo, A. (2018a). \#CH1. In Kidung Nawala (Jilid 1). Sidoarjo: UNUSIDA Press.

Purnomo, A. (2018b). Dua Kaki. In Kidung Nawala (Jilid 2). Sidoarjo: UNUSIDA Press. Purnomo, A. (2019a). Berpulang. In Syair Nimala. Sumenep: STIEBA Madura Press.

Purnomo, A. (2019b). Menyala. In Tenta Kimaya. Sumenep: STIEBA Madura Press. 
Purnomo, A. (2019c). Rindu di Ubun-Ubun. In Rassana Jlantir. Sumenep: STIEBA Madura Press.

Purnomo, A., \& Asitah, N. (2019a). Bapak

Samsuri. In Dhalubang Marta. Sumenep: STIEBA Madura Press.

Purnomo, A., \& Asitah, N. (2019b). Cantik. In Lembhar Jiwana. Sumenep: STIEBA Madura Press.

Purnomo, A., \& Asitah, N. (2019c). Pandai. In Tolesan Aditi. Sumenep: STIEBA Madura Press.

Purnomo, A., \& Asitah, N. (2019d). Sepekan Awal Tanpamu. In Arebhan Helai. Sumenep: STIEBA Madura Press.

Purnomo, A., \& Asitah, N. (2019e). Tangisnya. In Bhumi Bawera. Sumenep: STIEBA Madura Press.

Purnomo, A., \& Rosyidah, E. (2019). Kita. In Suweda Ate. Sumenep: STIEBA Madura Press.

Wikikids. (2018). Poezie. Retrieved June 23, 2019, from https://wikikids.n1/Poëzie 